\title{
Prediction of body weight using morphometric indices in giant African land snail in three zones of Imo state
}

${ }^{1 *}$ Ahamba, S. I., ${ }^{2}$ Ekugba, C.U., ${ }^{3}$ Kadurumba, O. E. and ${ }^{4}$ Ogundu, U. E.

${ }^{I}$ Department of Animal Science and Technology, School of Agriculture and Agricultural

Technology, Federal University of Technology PMB 1526 Owerri, Nigeria.

${ }^{2}$ Department of Animal Science, Faculty of Agriculture, Nnamdi Azikiwe University, Awka, Anambra State, Nigeria.

Corresponding author: ahambaifeanyi@futo.edu.ng/ahambaifeanyi@gmail.com;

Abstract

$+2347037261316$

Prediction of body weight using morphometric indices in giant African land snail (Achatina marginata) was studied for the three (3) agro-ecological zones in Imo State (Owerri, Okigwe and Orlu zones). One hundred and sixty (160) snails in Imo State were surveyed in course of this study. Data were generated through measurement of body weight, shell length, shell width, shell thickness, mouth length, weight of shell, weight of visceral, length of foot and thickness of foot. Data collected were subjected to regression analysis using SPSS statistical package. Results showed generally highly significant value $(P<0.01) R^{2}$ value and $R$-value across the zoness. Highly significant difference $(P<0.01)$ was observed in Owerri zone for the weight of shell, and the shell length. In Okigwe zone, only the weight of visceral showed a significant effect $(P<0.01)$, whereas, in Orlu zone also, the shell width, shell mouth length and foot thickness showed a significant effect $(P<0.01)$. The study therefore recommends that the linear model used, fits the data. Hence a comprehensive selection program for improvement of A. marginata in Imo State could be planned using the regressions coefficients obtained from the study.

Keywords: Snails, Prediction, Morphometric, traits

La Prédiction du poids corporel à l'aide d'indices morphométriques chez l'escargot terrestre géant africain dans trois zones de l'État de l'IMO

\section{Résumé}

La prédiction du poids corporel à l'aide d'indices morphométriques chez l'escargot terrestre géant africain (Achatina marginata) a été étudiée pour les trois (3) zones agro-écologiques de l'État d'Imo (zones Owerri, Okigwe et Orlu). Cent soixante (160) escargots de l'État d'Imo ont été étudiés au cours de cette étude. Les données ont été générées en mesurant le poids corporel, la longueur de la coquille, la largeur de la coquille, l'épaisseur de la coquille, la longueur de la bouche, le poids de la coquille, le poids du viscéral, la longueur du pied et l'épaisseur du pied. Les données collectées ont été soumises à une analyse de régression à l'aide du progiciel statistique SPSS. Les résultats ont montré une valeur $R 2$ et une valeur $R$ généralement très significatives $(P<0,01)$ dans les zones. Une différence très significative $(P<0,01)$ a été observée dans la zone d'Owerri pour le poids de la coquille et la longueur de la coquille. Dans la zone Okigwe, seul le poids des viscéraux a montré un effet significatif( $P$ $<0,01)$, alors que, dans la zone Orlu, la largeur de la coque, la longueur de la bouche de la coque et l'épaisseur du pied ont également montré un effet significatif $(P<0,01)$ que le modèle linéaire utilisé, ajuste les données. Par conséquent, un programme de sélection complet pour l'amélioration d'A. Marginata dans l'État de l'Imo pourrait être planifié en utilisant les coefficients de régression obtenus à partir de l'étude.

\section{Mots clés : escargots, prédiction, morphométrie, traits}




\section{Introduction}

Conventional and regular sources of animal protein in the country like beef, pork, goat meat, fish, poultry, and so on, are getting out of the reach of the common populace due to their high price coupled with the economic down-turn (Olayide, 2004). The only way to avert this problem is to bridge this gap and this could only be possible by making more available other various nonconventional animal protein sources like snail, cricket, and winged termite are now being explored. Study by Bamidele et al. (2018) shows that Snails are efficient producers of meat; they have high medical value, hence its alleged usage in curing cancer. As opined by Odunnaiya (1991), snails are also used in prevention and curing of diseases like hypertension, anaemia, and hemorrhoid and to restore virility in men. Apart from richness in nutritional value, Snail meat is becoming a highly relished delicacy in Nigeria and could however be taken with rice or in soup in place of meat or fish (Oben, 2008). It is highly nutritive, contain high protein and minerals (iron and phosphorus), but low in sodium, fat and cholesterol (Akinnusi, 2002; Ejidike, 2002). It has become important to improve the genetic performance of snails, so as to boost its production. This could be achieved by estimation of genetic parameter, correlation among performance traits in the breeding objectives and development of selection program for effective planning. The relationship between live body weight and body dimensions is very useful in the prediction of live body weight of animals (Kahlodi, 2014). According to Ozoje and Mgbere (2002), the final body weight of animals is a reflection of the sum total of the weight of all its component parts. This means that a change in any one of the component parts could result positively or negatively on the final body weight depending on the direction of the change.
There is therefore need to estimate the relationship between the body weight and other morphological traits in snail with a view to set up a breeding program. This study intends to ascertain the relationship between body weight and morphometric traits in A. marginata, hence, estimate the heritability of some of the morphometric traits of the specie.

\section{Materials and methods Location of the study}

The research was conducted in Imo state, South-East, Nigeria. Imo state lies between latitude $4^{\circ} 45^{\prime} \mathrm{N}$ and $7^{\circ} 15^{\prime} \mathrm{N}$ and longitude $6^{\circ} 50^{\prime} \mathrm{E}$. annual rainfall usually varies from $1990 \mathrm{~mm}$ to $2200 \mathrm{~mm}$. the mean annual temperature is above $20^{\circ} \mathrm{C}$ with an average annual relative humidity of $75 \%$.

\section{Samples and sampling method}

The survey was conducted in selected areas of Imo state taking into consideration the 3 agro-zones in the state. In Orlu zone 3 local government areas (Oguta, Njaba, and Nwangele), were randomly selected for survey. In Okigwe zones, 3 local government areas (Isiala mbano, Onuimo and Obowu) were considered. Similarly, 3 local government areas were selected for Owerri zone. They include, Ohaji egbema, Owerri west, and Ngor okpala. A total of 150 (50 from each zone) mature snails of average weight (75-125g) were randomly sampled in the selected local government areas of the state between June-July and used for the estimation of body weight and morphometric traits, during the field survey stage of the work. The animals were housed in a hutch made with a wire mesh.

\section{Data collection}

Data were collected on the morphological trait which includes body weight, shell length, shell width, shell thickness, shell mouth, and weight of shell, weight of visceral mass, foot length, and thickness of foot. The whole body weight, weight of 


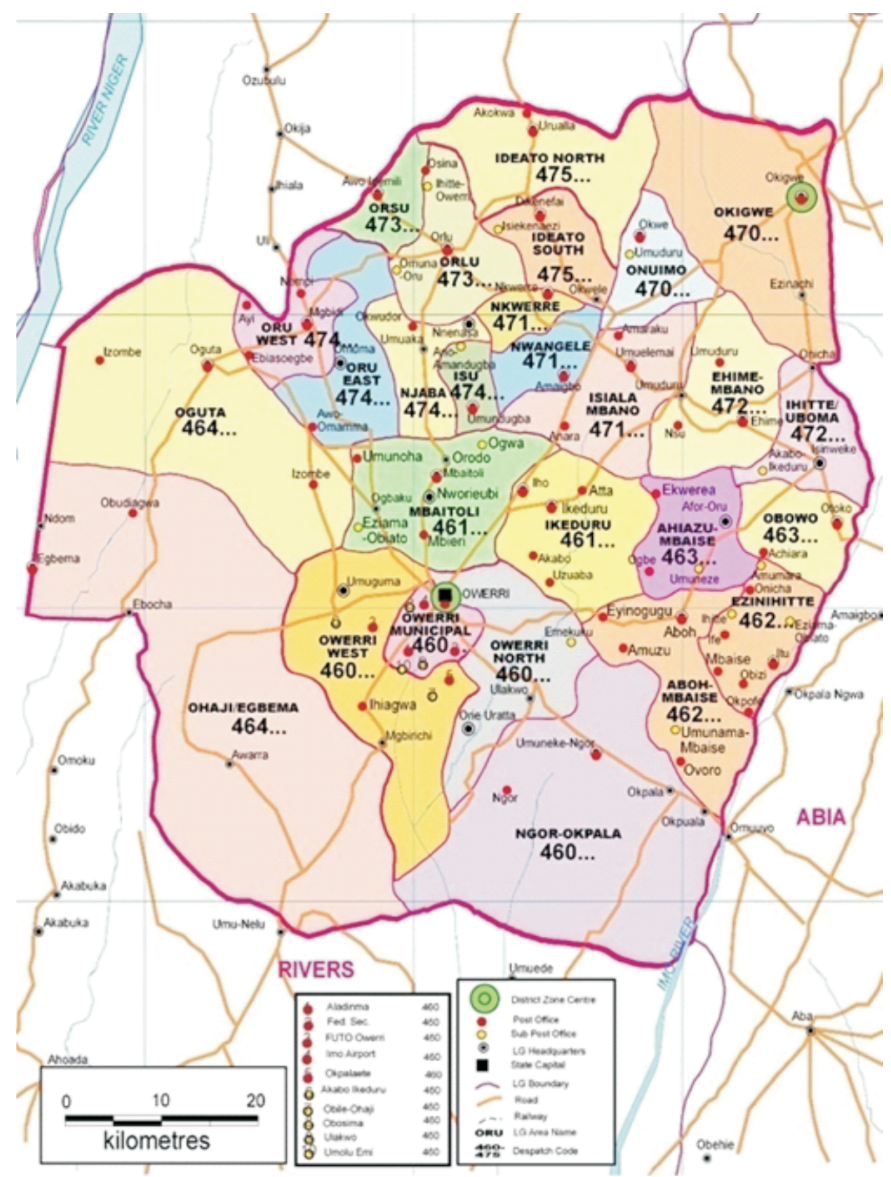

Fig.3.1. Map of Imo State, showing different Local Government Areas and communities

shell, weight of visceral was measured in grams using a $5 \mathrm{~kg}$ digital (sensitive) scale. The shell length, shell width, foot length, was measured in cm using the Venier scale. Shell thickness, and foot thickness were measured in mm using the micrometer screw gauge. Finally, the shell mouth was measured in $\mathrm{cm}$ using a rope and a meter rule. Body weight $(\mathrm{kg})$ and morphometric traits were measured as described by Olawunmi et al. (2008).

\section{Statistical analysis}

The SPSS (1996) statistical package was used to evaluate the multi-regression analysis with model below; $\mathrm{Y}=\mathrm{a}+\mathrm{b}_{1} \mathrm{x}_{1}+\mathrm{b}_{2} \mathrm{x}_{2}+\ldots \ldots \mathrm{b}_{\mathrm{k}} \mathrm{x}_{\mathrm{k}}+\mathrm{e} \ldots \ldots$... $q u 1$ Where,
$\mathrm{Y}=$ Body weight (dependent variable)

$\mathrm{X}_{1}-\mathrm{X}_{\mathrm{K}}=$ Morphometric traits (independent variable)

$b=$ regression coefficient of morphometric traits

$\mathrm{a}=$ intercept

\section{Results and discussion}

The result of the multiple regression analysis of body weight on the morphometric traits of Achatina. marginata (A. marginata) in Owerri zone as shown in Table I below reveals a significant $(\mathrm{P}<0.05) \mathrm{R}^{2}$ and $\mathrm{R}$ values of 0.888 and 0.94 respectively. Most morphometric traits showed a positive regression coefficient ranging from 0.08 to 16.84 for the foot length and shell length respectively, 
although none, except the foot length was significant. Positive correlation here denotes that the pairs of traits; body weight and morphometric traits have direct relationship or they are controlled by same gene in the same direction as earlier pointed out by Ibom (2009) and Okon et al. (2009). However, the value disagrees with the low $\mathrm{R}^{2}$ value (4.7\%) by Okon and Ibom (2011) for hatching weight and morphometric traits. The observed positive regression coefficient values for the morphometric traits (shell length, shell width, shell thickness, shell mouth, weight of shell, weight of viscera, foot length and foot thickness reveals that, a unit increase in any of the traits, would amount to an expected increase of the body weight by a constant amount of $16.84,11.06,8.67,9.02,0.04$, $0.04,0.46$ and 0.08 respectively.

Table 1: Multiple regression analysis of body weight, on morphometric traits of A . marginata in Owerri zone

\begin{tabular}{|c|c|c|c|}
\hline Variable & symbol(term) & T value & Coeff+SEM \\
\hline Constant term & A & - & $-212.23 \pm 0.810$ \\
\hline Shell length (cm) & b1 & $8.07 * *$ & $16.84 \pm 0.09$ \\
\hline Shell width $(\mathrm{cm})$ & $\mathrm{b} 2$ & $4.39 *$ & $11.06 \pm 0.52$ \\
\hline Shell Thickness (cm) & b3 & $3.48^{*}$ & $8.67 \pm 0.49$ \\
\hline Shell mouth $(\mathrm{cm})$ & $\mathrm{b} 4$ & $3.32 *$ & $9.02 \pm 0.72$ \\
\hline Weight of shell (g) & b5 & $-0.39 \mathrm{NS}$ & $0.04 \pm 0.10$ \\
\hline Weight of viscera $(\mathrm{g})$ & b6 & $-0.43 \mathrm{NS}$ & $0.04 \pm 0.93$ \\
\hline Foot length $(\mathrm{cm})$ & b7 & $-0.74 \mathrm{NS}$ & $0.46 \pm 0.63$ \\
\hline Foot thickness $(\mathrm{cm})$ & $\mathrm{b} 8$ & $1.07 \mathrm{NS}$ & $0.08 \pm 0.07$ \\
\hline $\begin{array}{l}\text { Multiple co -eff of } \\
\text { determination }(\%)\end{array}$ & $\mathrm{R}^{2}$ & & $89 \%$ \\
\hline Multiple Correlation & $\mathrm{R}$ & & $94.2 \%$ \\
\hline \multirow{2}{*}{ F-value (calculated) } & & & 8.94 \\
\hline & $(\mathrm{p}<0.05)$ & & $8.94^{\mathrm{NS}}$ \\
\hline F-value (tabulated) & $(\mathrm{p}<0.01)$ & & $5.47 * *$ \\
\hline
\end{tabular}

Result of the multiple regression analysis of body weight on the morphometric traits of $A$. marginata in Okigwe zone in Table II, reveals a significant $(p<0.05) R$ value of 0.607 , and a non-significant $R^{2}$ value of 0.368. Most morphometric traits showed a positive regression coefficient ranging from 0.13 to 14.94 for the foot length and shell thickness respectively, although none, except the foot length showed a significantvalue. The mouth length had a negative coefficient value of -18.6. This value agrees with the low $\mathrm{R}^{2}$ value $(4.7 \%)$ by Okon and Ibom (2011) for hatching weight and morphometric traits The observed positive regression coefficient values for the shell length, shell thickness, weight of shell, weight of viscera, foot length and foot thickness indicates that a unit increase in any of the morphometric traits, would bring about an expected increase of the body weight by $10.17,14.94,5.87,0.13,0.88$ and 0.24 respectively. The observed negative value of $b$ for mouth length indicates that any unit decrease in the trait will lead to a concordance decrease of the body weight by a factor, 18.60. However, positive correlation here denotes that the pairs of traits, body weight and morphometric traits have direct relationship or at least they are controlled by same gene in the same direction as earlier pointed out by Ibom 


\section{Ahamba, Ekugba, Kadurumba and Ogundu}

(2009) and Okon et al. (2009). More so, the negative intercept value obtained, signifies that in the absence of all studied morphometric traits, the body weight will decrease by $138.39 \pm 110.36$. This agrees with the fact that snail weight can be predicted using quantitative or morphometric trait as predicted by Okon and Ibom (2011). T-test showed that none of the morphometric traits was significant. This could be attributed to few data set used from this zone.

Table 2: Multiple regression analysis of body weight, on morphometric trai ts of $A$. marginata in Okigwe zone

\begin{tabular}{llll}
\hline Variable & symbol(term) & T value & $-138.39 \pm 110.36$ \\
\hline & & & $10.17 \pm 0.6$ \\
Constant term & A & - & $14.94 \pm 0.04$ \\
Shell Length (cm) & b1 & $2.20 \mathrm{NS}$ & $-18.60 \pm 0.18$ \\
Shell Width (cm) & b2 & $1.86 \mathrm{NS}$ & $5.87 \pm 5.11$ \\
& & & $0.10 \pm 0.08$ \\
Shell Thickness (cm) & b3 & $-1.41 \mathrm{NS}$ & \\
Shell mouth (cm) & $\mathrm{b} 4$ & $1.15 \mathrm{NS}$ & \\
Weight of shell $(\mathrm{g})$ & $\mathrm{b} 5$ & $0.33 \mathrm{NS}$ & \\
Weight of Viscera $(\mathrm{g})$ & $\mathrm{b} 6$ & $0.46 \mathrm{NS}$ & $0.13 \pm 0.28$ \\
Foot Length (cm) & $\mathrm{b} 7$ & $0.19 \mathrm{NS}$ & $0.88 \pm 4.74$ \\
Foot Thickness (cm) & $\mathrm{b} 8$ & $0.09 \mathrm{NS}$ & $0.24 \pm 2.55$ \\
Multiple co -eff of & $\mathrm{R} 2$ & & $36.8 \%$ \\
determination $(\%)$ & & & $60.7 \%$ \\
Multiple Correlation & $\mathrm{R}$ & & 2.17 \\
F-value (calculated) & & & $1.96 *$ \\
F-value (tabulated) & $(\mathrm{p}<0.05)$ & & $3.42^{\mathrm{NS}}$ \\
\hline
\end{tabular}

a. $* \mathrm{P}<0.05 \quad * * \mathrm{P}<0.01 \quad$ NS- non significant

b. Dependent Variable: BDYWT

The multiple regression analysis of body weight on the morphometric traits of $A$. marginata in Orlu zone as shown in Table III shows a highly significant $(\mathrm{p}<0.01) \mathrm{R}^{2}$ and $R$ value of 0.95 and 0.975 respectively. The $\mathrm{R}^{2}$ value indicates that the linear model has accounted for $95 \%$ of variability in the data. This gives the impression that the model fits the data, whereas, the $\mathrm{R}$ value indicates that for every change in the morphometric traits, the body weight is $97.5 \%$ likely to change, supporting the highly significant positive correlation among morphometric traits and body weight earlier reported by Ibom et al. (2010). The observed morphometric traits with positive correlation coefficient: shell length, shell width, shell thickness, mouth length, weight of shell, foot length and foot thickness, shows that any unit increase in any of the traits, will amount to 16.84 , $11.06,8.67,9.02,0.46$ and 0.08 increase in the body respectively. This result is in line with the findings of Ibom (2009) and Okon et al. (2009), that morphometric traits of snails are directly related to the body weight of snail. On the other hand, the observed negative values of $b$ for weight of shell and weight of viscera indicate that, for any unit decrease in the traits, there will be a decrease of the body weight by 0.04 . The negative intercept value obtained reveals that in the absence of all studied morphometric traits, the body weight will decrease by $212.23 \pm 18.1$. This agrees with the fact that snail weight can be predicted using quantitative or morphometric trait as predicted by by Okon and Ibom (2011). The shell length showed highly significant 
$(\mathrm{p}<0.01)$ T-value at $80 \%$ confidence level, while shell width, shell thickness and mouth length showed a significant $(\mathrm{p}<0.05)$ T-value, and other morphometric traits were not significant. This is an indication that any improve on any of these traits will result to an increase in the body weight of snail, as pointed out earlier by Ibom (2009).

Table 3: Multiple regression analysis of body weight, on morphometric traits of $\boldsymbol{A}$. marginata in Orlu zone

\begin{tabular}{llll}
\hline Variable & symbol(term) & T value & Coeff+SEM \\
\hline & & & \\
Constant term & A & - & $-136 \pm 0.22$ \\
Shell length (cm) & b1 & $4.72 *$ & $23.73 \pm 0.03$ \\
Shell width (cm) & b2 & $0.33 \mathrm{NS}$ & $2.56 \pm 0.68$ \\
Shell thickness (cm) & b3 & $0.36 \mathrm{NS}$ & $5.74 \pm 0.12$ \\
Shell mouth (cm) & $\mathrm{b} 4$ & $-0.82 \mathrm{NS}$ & $-5.27 \pm 0.43$ \\
Weight of shell (g) & $\mathrm{b} 5$ & $0.34 \mathrm{NS}$ & $0.13 \pm 0.35$ \\
Weight of viscera (g) & $\mathrm{b} 6$ & $-0.48 \mathrm{NS}$ & $-0.14 \pm 0.29$ \\
Foot length (cm) & $\mathrm{b} 7$ & $-0.04 \mathrm{NS}$ & $-0.18 \pm 0.48$ \\
Foot thickness (cm) & $\mathrm{b} 8$ & $1.71 \mathrm{NS}$ & $4.28 \pm 0.51$ \\
Multiple co -eff of & $\mathrm{R} 2$ & & $88.8 \%$ \\
determination (\%) & & & \\
Multiple Correlation & $\mathrm{R}$ & & $94.2 \%$ \\
F-value (calculated) & & & 8.94 \\
F-value (tabulated) & $(\mathrm{p}<0.05)$ & & $8.944^{\mathrm{NS}}$ \\
& $(\mathrm{p}<0.01)$ & & $5.47^{*} *$ \\
\hline
\end{tabular}

a. $* \mathrm{P}<0.05 \quad * * \mathrm{P}<0.01 \quad$ NS- non significant

b. Dependent Variable: BDYWT

The result of the multi regression analysis of body weight of the morphometric traits of A. Marginata in Imo- State, shown in Table IV reviews regression coefficients, $R$ and $R^{2}$ values of 0.86 and 0.74 respectively. The R-values were positive for foot thickness, weight of visceral, weight of shell, shell length and shell mouth ranging between 0.058 for foot thickness to 12.063 for mouth length respectively. The intercept, a, had a negative value of 127.051. The $\mathrm{T}$ - test values were generally not significant $(\mathrm{P}>0.05)$ for all the other traits except for the shell length which was highly significant $(\mathrm{P}<0.01)$ and the shell mouth and the weight of shell that were significant $(\mathrm{P}<0.05)$. The relative high $\mathrm{R}^{2}$ value estimated for multi regression analysis of body weight on morphometric traits of A. marginata in Imo State shows that the linear model has account for the variability in data. This shows the fact that the model is fit for the data. The observed positive b-coefficient value for morphometric traits (shell length, shell mouth, weight of shell, weight of visceral and foot thicken in Imo state, indicates that any unit increase in any of the above traits, the body weight would be expected to increase by $10.001,12-063,0.221,0.213$ and 0.058 respectively. The observation is in line with the findings of Ibom (2009) and Okon et al. (2009), that morphometric traits of snail is directly related to the body weight of the snail. Whereas, the negative b-coefficient value of shell width, shell thickness, and foot length indicates that any unit increase in any of the 3 traits above, will bring about an expected 0.97, 1.209 and 0.168 decrease respectively in the body weight of the snail. The negative intercept a, value indicates that if the value of all the studied morphometric trait is zero (0), the body weight of the snail would be expected 
to decrease by the value, $127.05 \pm 32.35$. the $0.74 \mathrm{R}$ value indicates that both the body weight and other morphometric traits vary together about $72 \%$.

Table 4. Multiple regression analysis of body weight, on morphometric traits of $A$. marginata in Imo State

\begin{tabular}{|c|c|c|c|c|c|}
\hline Regression equation & R (\%) & $R^{2}(\%)$ & S.E & $\mathbf{T}$ & SIG \\
\hline $\mathrm{BDYWT}=-127.051 \pm 32.35$ & 86 & 74 & & & $* *$ \\
\hline +10.001SHLLENT & & & \pm 3.16 & & $* *$ \\
\hline -0.970 SHLLWTD & & & \pm 0.90 & & NS \\
\hline -1.209 SHLLTHKNS & & & \pm 3.25 & & NS \\
\hline +12.063 MUTHLNT & & & \pm 4.51 & & $*$ \\
\hline$+0.221 \mathrm{WT}$ of SHLL & & & \pm 0.10 & & $*$ \\
\hline$+0.213 \mathrm{WT}$ of VISCRL & & & \pm 0.11 & & NS \\
\hline -0.168 FOOTHNKNS & & & \pm 0.46 & & NS \\
\hline$+0.058 \mathrm{FOOT} \mathrm{LNT}$ & & & \pm 0.19 & & NS \\
\hline
\end{tabular}

a. $\quad * \mathrm{P}<0.05 \quad * * \mathrm{P}<0.01 \quad$ NS- non significant

b. Dependent Variable: BDYWT

Table 5 show the repeatability estimate of some morphometric trait of $A$. marginata in the 3 zones of Imo State. Shell thickness and shell width had low repeatability estimate of 0.14 and 0.24 respectively, while the shell length has a high repeatability estimate of 0.53 and body weight had a medium estimate of 0.37 . The $r$ value of the repeatability estimates of some morphometric traits of A. marginata in the 3 zones of Imo State ranges between a low value, 0.14 to a high value, 0.53 , for shell thickness and shell length respectively. This observation agrees with the finding of Okoro and Ogundu (2006), that growth traits have heritability and repeatability ranging from low to high value. The low, medium, and high repeatability value for shell thickness and shell width, body weight and and shell length respectively, signifies that shell thickness and shell width traits with low repeatability needs a different method of selection. Body weight traits with a medium repeatability, shell length traits of snail with a high repeatability gives the impression that similar selection method could be used for these two traits. Thus the repeatability value can be used as an important tool for selection for improvement of flock performance, in breeding programs as opined by Dzakuma et al.(1982),

Table 5: Repeatability estimates of some morphometric traits of $A$. marginata in the three zones of Imo State

\begin{tabular}{lllll}
\hline Traits & $\boldsymbol{\sigma}^{\mathbf{2}} \mathbf{w}$ & $\boldsymbol{\sigma}^{\mathbf{2}}$ & $\mathbf{r}$ & $\mathbf{S E}(\mathbf{R})$ \\
Body weight & 208.18 & 347.846 & 0.37 & 0.08 \\
Shell length & .274 & .415 & 0.53 & 0.07 \\
Shell width & 79.42 & 278.35 & 0.24 & 0.20 \\
Shell thickness & .021 & .129 & 0.14 & 0.19 \\
\hline
\end{tabular}

a. $\boldsymbol{\sigma}^{2} \mathbf{w}=\operatorname{Var}\left(\right.$ LGA location), $\boldsymbol{\sigma}^{2}{ }_{\mathbf{B}}=\operatorname{var}($ Error $)$

\section{Conclusion}

The need or quest for animal protein supply cannot be possible without the inclusion of non-conventional sources of animal protein into human diet, to make meat affordable for both the rich and the poor. In order, to ensure the sustainability of the enterprise, the productive capability of the animal must be improved. This cannot be achieved without considering the quantitative measurements, correlation among performance traits and development of 
selection programs for effective planning. The important results from this study can be summarized as follows. The shell length was highly significant $(\mathrm{P}<0.01)$ while the shell mouth and weight of shell were significant $(\mathrm{P}<0.05)$, the correlation coefficient $R$, and the $R^{2}$ showed no significant difference in the general study of Imo state and a high repeatability estimate for shell length, medium for body weight and low for shell thickness and shell width, was recorded for A. marginata in Imo State.

\section{Recommendation}

This study therefore, recommends selection based on the morphometric trait(s) with a high repeatability in the zones; that is, selection of body weight could be combined with the prediction of morphometric traits at the different zones, thus; selection of snails can be based on weight of shell and shell length, weight of the visceral and shell width, shell mouth and foot thickness for Owerri, Okigwe and Orlu zone, respectively. Hence a comprehensive selection program could be planned for improvement of $A$. marginata in Imo State using the repeatability estimate values and regressions coefficients obtained from this study.

\section{References}

Akinnusi, O. 2002. Introduction to Snails and Snail Farming, Triolas publishing company, Abeokuta. p. 70.

Bamidele, J. A., Ademolu, K. O., Idowu, A. B., Aladesida, A. A., and Oladele, A. O. 2018. Biochemical and nutritional composition of giant African Land Snail (Archachatina marginata) from Southwest Nigeria. Pertanika Journal of Tropical Agricultural Science 41(1): 129 138.

Dzakuma, J. M., Whiteman, J. V. and McNNew, R. W. 1982. Repeatability of Lambing rate. Journal of Animal Science. 54: 540-543.

Ejidike, B. N. 2002. Snail rearing practices in Southern Nigeria. Proceeding of $27^{\text {th }}$ Annual Confernece of Nigerian Society for Animal production (NSAP), Akure, Nigeria, pp 307-308.

Ibom, L. A. 2009. Variations in Reproductive and Growth performance traits of White-skinned x Black-skinned African giant snail hatchlings (Archachatina marginata) in Obubra, Nigeria, Doctor of Philosophy Thesis, Department of Animal Science, University of Calabar, Calabar, Nigeria.

Ibom, L. A., Okon, B., Williams, M. E. and Etukudo, O. M. 2010. Effects of Parity on Breeding and Morphometric Traits of Eggs and Hatchlings of F1Crossbred of Snails (Archachatina marginata var. saturalis), Journal of Agriculture, Biotechnology and Ecology, 3(1):36 -43 .

Kahlodi, M. A. 2014. Assessment of the relationship between body weight and body measurements in indigenous goats using path analysis. Animal production. South Africa. 213b.

Oben, F. T, Etchu, K. and Mafemi, M. 2008. Comparative performance of climatic variables and dietary influence on the performance of three edible snail species using intensive cage housing system in Cameroon. Buk. Anim. Health prod. Afr. 56:345352.

Odunnaiya, O. 1991. Studies on the Growth Rate of $A$. marginata Fed Pawpaw Leaf, Water-leaf and Maizechaff. Unpublished B. agric thesis, Ogun State University, Ago-Inoya Nigeria, 25-40.

Okon, B and Ibom, L. A. 2011. Phenotypic 
correlation and body weight prediction using Morphometric traits of snails in Calabar, Nigeria. Ethiopian Journal of Environmental Studies and Management, 4(3): 321 328

Okon, B., Ibom, L. A., Ekpo, I. A., Ewa, E. C. 2009. Evaluation of Reproductive and Some Egg Quality Parameters of Albino Snails (Archachatina marginata S), Journal of Applied Sciences (JAS), 12(1):8234-8241

Okoro, V. M. O and Ogundu, U. E. 2006. Genetic variabilities of growth traits in two turkey breeds in south Eastern Nigeria. In: proceedings of the $31^{\text {st }}$ Annual conference of the Nigerian society for Animal production (NSAP) 31:5-8.
Olawumni, O. O., Solako, A. and Afuwape, A. A. 2008. Morphometric differentiation and assessment of function of the Fulani and Yoruba ecotype indigenous chickens of Nigeria. International journal of morphology 26(4): 975 - 980.

Olayide, O. E. and Ikpi, A. E. 2013. Agricultural production and rural welfare in Nigeria. Assessing agricultural production and its impact on rural welfare. Pp 173.

Ozoje, M. O. and Mgbere, O. O. 2002. Coat pigmentation effects in West African Dwarf goats; live weight and body dimension. Nigerian journal of Animal production. 29: 5-10.

SPSS, 1990. Statistical Package for Social Science-New York.

Received: $24^{\text {th }}$ May, 2020

Accepted: $12^{\text {th }}$ December, 2020 